\title{
Workshop on the ecosystem and fisheries of the Coral Sea: an Australian perspective on research and management
}

\author{
Jock W. Young • A. David McKinnon - Daniela Ceccarelli • Richard Brinkman • \\ Rodrigo H. Bustamante $\cdot$ Mike Cappo $\cdot$ Cathy Dichmont $\cdot$ Peter Doherty • \\ Miles Furnas • Daniel Gledhill $\cdot$ Shane Griffiths $\cdot$ Trevor Hutton • \\ Ken Ridgway $\cdot$ David Smith $\cdot$ Tim Skewes $\cdot$ Alan Williams $\cdot$ Anthony J. Richardson
}

Received: 5 December 2011 / Accepted: 7 December 2011 / Published online: 23 December 2011

(C) The Author(s) 2011. This article is published with open access at Springerlink.com

\begin{abstract}
This report summarizes a workshop on the Coral Sea to determine key research findings and identify the research gaps needed to support sustainable management of a proposed Coral Sea Marine
\end{abstract}

J. W. Young $(\bowtie) \cdot$ D. Gledhill $\cdot$ K. Ridgway .

D. Smith · A. Williams

Wealth from Oceans Flagship, CSIRO Marine and

Atmospheric Research, GPO Box 1538, Hobart, TAS

7000, Australia

e-mail: Jock.Young@csiro.au

A. David McKinnon - R. Brinkman .

M. Cappo · P. Doherty · M. Furnas

Australian Institute of Marine Science, PMB No. 3, TMC,

Townsville, QLD 4810, Australia

D. Ceccarelli

Marine Ecology Consultant, P.O. Box 215,

Magnetic Island, QLD 4819, Australia

R. H. Bustamante - C. Dichmont - S. Griffiths ·

T. Hutton - T. Skewes - A. J. Richardson

Wealth from Oceans Flagship, CSIRO Marine and

Atmospheric Research, Ecosciences Precinct,

GPO Box 2583, Brisbane, QLD 4102, Australia

\section{A. J. Richardson}

Centre for Applications in Natural Resource Mathematics, School of Mathematics and Physics, The University of Queensland, St Lucia, QLD 4072, Australia

\section{A. J. Richardson}

Environmental Decisions Group, School of Biological Sciences, The University of Queensland, Brisbane 4072, Australia
Reserve. Key research questions included determining the connectivity of apex predators with the broader southwest Pacific Ocean, and assessing the regions' biodiversity in relation to seabed topography and oceanographic processes. The workshop concluded noting the importance of engaging surrounding countries in maintaining the sustainability and uniqueness of the Coral Sea.

Keywords Coral Sea - Food-webs - Biodiversity · Pelagic ecosystem $\cdot$ Benthic ecosystem $\cdot$ Marine parks

\section{Introduction}

The Coral Sea is a marginal sea bounded by Australia, New Caledonia (France), Papua New Guinea, Solomon Islands and Vanuatu. It is a rare example of a relatively pristine tropical ocean environment, with few impacts of fishing, pollution and mining (Halpern et al. 2008). However, large-scale tuna fisheries exist both within the Coral Sea and in the EEZs of surrounding western Pacific island nations, and many of the targeted species may move south into the Coral Sea with changing climate and oceanographic conditions (Hobday 2010). It adjoins the hyper-diverse Great Barrier Reef (GBR) and the Coral Triangle, yet much of the biodiversity of the Coral Sea remains unknown, particularly in deeper waters. The Australian portion of the Coral Sea is a tropical ecosystem where the capacity exists to combine research and management to sustain and conserve 
biodiversity and test broader management scenarios (Mora et al. 2009). There is a process underway in Australia to establish the world's largest marine park in the Coral Sea within the Australian Exclusive Economic Zone, combining no-take reserves and multiple use zones (Cressey 2011). Research in the Coral Sea and international collaboration are urgently needed to inform its future management.

With increasing interest in the region, we held a workshop to support the development of a research plan for Australia's Coral Sea territory, defined as the area from the Shelf break seaward to the Australian Exclusive Economic Zone. We discussed major research areas and management issues in the Coral Sea via a series of presentations by experts working in the region. Here we summarize the main themes, describing our current knowledge and identifying major gaps and issues. We conclude with a list of research priorities, and potential areas for collaboration with neighbouring countries.

\section{The workshop}

The workshop started with a series of themed talks on what we presently know and where the major knowledge gaps presently lie. These themes are summarized in Table 1. Following is a brief summary of presentations and an outline of future priorities and research needs.

Table 1 Major knowledge areas and gaps for the Coral Sea by research theme

\begin{tabular}{|c|c|c|}
\hline Themes & Knowledge & Gaps \\
\hline Topography & Basin-scale topography; complex bathymetry & $\begin{array}{l}\text { Fine-scale mapping (e.g. some seamounts are } \\
\text { unnamed); evolutionary processes at scales relevant } \\
\text { to biology }\end{array}$ \\
\hline $\begin{array}{l}\text { Physical } \\
\text { oceanography }\end{array}$ & $\begin{array}{l}\text { Broad-scale circulation; effect of topographic features } \\
\text { enhancing local mixing }\end{array}$ & $\begin{array}{l}\text { Drivers of variability (e.g. ENSO) and response of } \\
\text { individual jets }\end{array}$ \\
\hline Plankton & $\begin{array}{l}\text { Oligotrophic character dominated by picoplankton and } \\
\text { microbial processes }\end{array}$ & $\begin{array}{l}\text { Little knowledge of pelagic biodiversity; } \\
\text { Understanding topographic controls on } \\
\text { productivity; trophic fate of productivity }\end{array}$ \\
\hline Mid-trophics & $\begin{array}{l}\text { Role of myctophids and squid in top predator } \\
\text { aggregations }\end{array}$ & Squid and fish taxonomy and distribution \\
\hline Large pelagics & $\begin{array}{l}\text { Ecology and niche segregation of commercial top } \\
\text { predators; Only known black marlin spawning } \\
\text { ground; increasing knowledge of neritic tunas }\end{array}$ & $\begin{array}{l}\text { Population connectivity outside the Coral Sea and } \\
\text { migration pathways; Little knowledge of unfished } \\
\text { species }\end{array}$ \\
\hline $\begin{array}{l}\text { Benthic and } \\
\text { demersal biota }\end{array}$ & $\begin{array}{l}\text { Shallow }(<20 \mathrm{~m}) \text { reef communities; some knowledge } \\
\text { of deeper demersal fish in the southern plateaux }\end{array}$ & $\begin{array}{l}\text { Biodiversity of bottom fish and invertebrates poorly } \\
\text { known. Little knowledge of demersal fish, } \\
\text { especially in the north, and virtually none for } \\
\text { invertebrates }\end{array}$ \\
\hline $\begin{array}{l}\text { Threatened, } \\
\text { endangered and } \\
\text { protected species }\end{array}$ & $\begin{array}{l}\text { Population dynamics and nesting success for seabirds } \\
\text { and sea turtles from a few cays; some knowledge of } \\
\text { the genetic structure of sea turtle and humpback } \\
\text { whale populations }\end{array}$ & $\begin{array}{l}\text { Occurrence, distribution and migration pathways for } \\
\text { most species unknown; the mechanism behind the } \\
\text { negative effect of ENSO on bird success }\end{array}$ \\
\hline Foodweb & $\begin{array}{l}\text { Broad understanding of some aspects of mid-and } \\
\text { higher trophic levels in pelagic. Growing } \\
\text { understanding of short and long foodwebs in relation } \\
\text { to top predator fishes }\end{array}$ & $\begin{array}{l}\text { Limited information for microbial, gelatinous and } \\
\text { benthic foodwebs }\end{array}$ \\
\hline Fishing & $\begin{array}{l}\text { Invertebrate and ornamental fishing on most reefs well } \\
\text { documented; low demersal fisheries productivity } \\
\text { (e.g. eteline snappers); good catch records for the } \\
\text { Australian pelagic fleet }\end{array}$ & $\begin{array}{l}\text { Stock connectivity for large pelagic fish in the greater } \\
\text { west Pacific; No consistent, quantitative, fisheries- } \\
\text { independent catch records for gamefish industry }\end{array}$ \\
\hline $\begin{array}{l}\text { Ecosystem } \\
\text { modelling }\end{array}$ & $\begin{array}{l}\text { Existing EwE of pelagic ecosystem and qualitative } \\
\text { models of various systems; development of complex } \\
\text { whole-of-system models and those of intermediate } \\
\text { complexity }\end{array}$ & $\begin{array}{l}\text { Data for parameterization and process understanding } \\
\text { in the region (e.g. bentho-pelagic coupling) }\end{array}$ \\
\hline
\end{tabular}


Physical oceanography

The defining feature of the circulation in the Coral Sea is the South Equatorial Current (SEC). Its bifurcation against the Australian continental margin forms the clockwise Coral Sea Gyre to the north and the southward flowing East Australian Current (EAC). The SEC is a pathway for water mass transport between mid-latitudes and equatorial regions, with a potential contribution to the propagation of climate signals across the Pacific Ocean. Within the Coral Sea, the SEC comprises narrow filaments and jets controlled by the complex island, reef, seamount and ridge topography (Fig. 1). The interaction of the regional scale flows with topographic features alters local mixing processes and results in local biological responses. Major knowledge gaps in our understanding of the oceanography include drivers of seasonal, interannual and multi-decadal variability, with a particular focus on the response of the separation of flow around islands and resultant changes in relative intensities of jets. This uncertainty has relevance to the strength of the EAC, upwelling on the margin of the GBR, connectivity within the Coral Sea and between the Coral Sea and adjoining water bodies, and northsouth connectivity on the GBR. Seabed topography was not covered in the workshop but was seen as an important area for research, especially due to effects on the regional oceanography and as habitat for benthic and bentho-pelagic communities.

Plankton productivity and zooplankton

Near-surface waters of the Coral Sea are warm, clear, oligotrophic, have a deep euphotic zone, and are characterized by low phytoplankton biomass. Phytoplankton communities are dominated by small $(<2 \mu \mathrm{m})$ cyanobacteria (e.g. Prochlorococcus and Synechococcus). Measured primary production rates in oceanic waters of the Coral Sea average between 300 and $400 \mathrm{mg} \mathrm{C} \mathrm{m}^{-2}$ day $^{-1}$ and are similar to those found in low latitude gyres elsewhere in subtropical and tropical waters. Higher production rates have been measured along the barrier reef margins of the oceanic Coral Sea, generally the result of episodic upwelling of nutrient-enriched thermocline waters. The diversity and response to enrichment of the zooplankton of the Coral Sea is poorly known, with research conducted

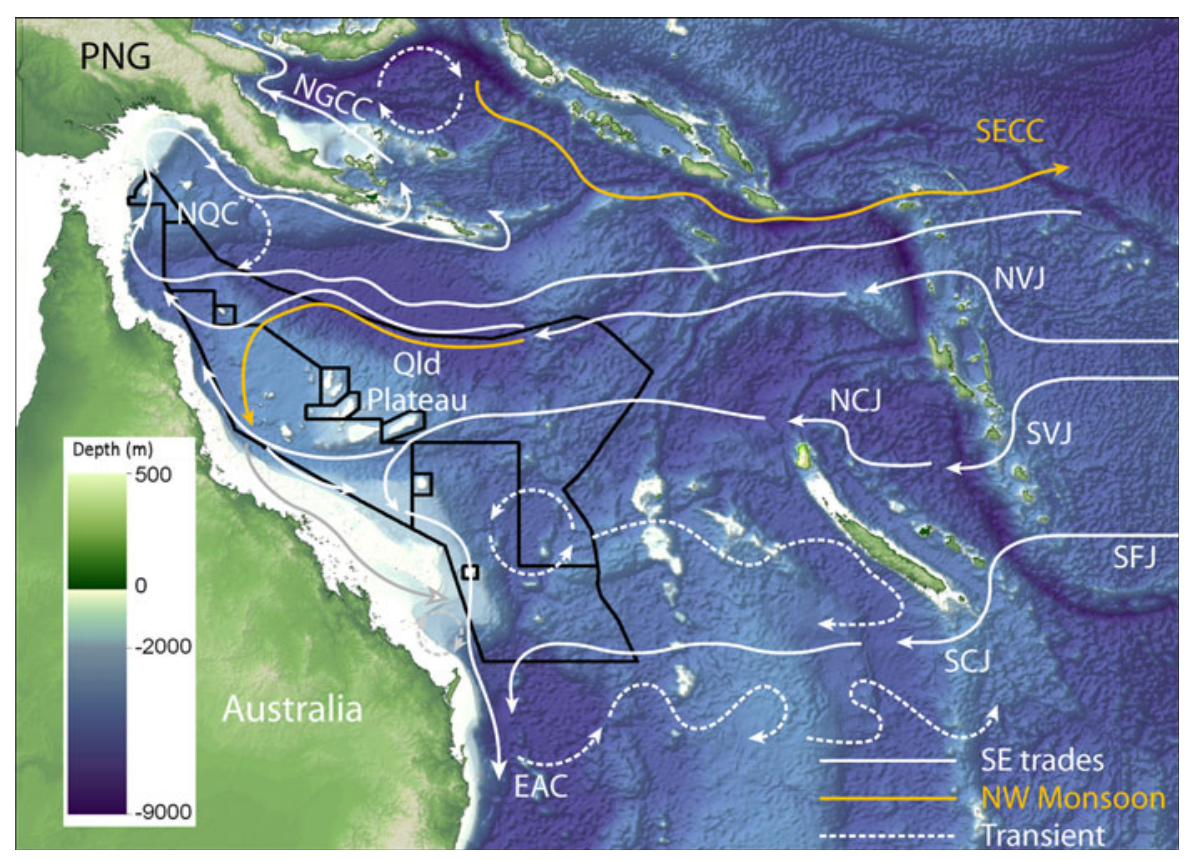

Fig. 1 Bathymetry (shading) and circulation features (vectors) of the Coral Sea. Major currents shown are the East Australian Current (EAC), North Queensland Current (NQC), New Guinea Coastal Current (NGCC), South Caledonia Jet (SCJ), North
Caledonia Jet (NCJ), North Vanuatu Jet (NVJ), South Vanuatu Jet (SVJ), South Fiji Jet (SFJ) and the South Equatorial Counter Current (SECC). Black lines indicate region of proposed Commonwealth marine reserve 
on the margins of the Coral Sea along the Great Barrier Reef (e.g. GBR Expedition 1928-1929) or off islands close to the outer Great Barrier Reef (Suthers et al. 2004, 2006). All studies have been confined to epipelagic waters and use comparatively coarse plankton nets $(>200 \mu \mathrm{m})$ that do not quantitatively sample the most numerous small zooplankton in tropical seas. Key knowledge gaps for plankton include the importance of bacterial production, the utility of primary production models based on ocean colour when chlorophyll usually peaks in the subsurface, and unquantified biodiversity of the zooplankton. For example, the zooplankton biodiversity in the Coral Sea is likely to be similar to that of similar latitudes in the Indian Ocean, where one family of copepods had $>60$ representatives, most of which were either new species or new records for Australia (David McKinnon, unpublished data).

\section{Micronekton}

There have been few studies of micronekton (midwater fauna ranging in length from 2 to $20 \mathrm{~cm}$ ) in the Coral Sea. A north-south survey of midwater fish and crustacea noted that Coral Sea myctophids were similar in composition to those of the EAC, but significantly different from those of the Tasman Sea (Griffiths and Wadley 1986). Aggregations of lanternfish were identified as possibly supporting aggregations of yellowfin and bigeye tuna in the Queensland Trough (McPherson 1991). Recent studies have expanded on the original finding, indicating that lanternfish spawning aggregations are fed upon by spawning aggregations of yellowfin and bigeye tuna in spring-summer in the Queensland Trough and in the vicinity of the Cairns Seamount (Flynn and Paxton, pers. comm.). The distribution and abundance of cephalopod species has been examined from predator stomach collections in the southern Coral Sea, but given their importance in top predator food webs in the region, are relatively understudied (Lansdell and Young 2007; Young et al. 2010). An acoustic survey at the southern edge of the Coral Sea showed significantly higher biomass of micronekton than previously reported elsewhere, underlining the importance of the micronekton to pelagic food webs generally (Kloser et al. 2009). Broader acoustic surveys, needed for ecosystem models being developed for the region, are planned (Kloser, pers. comm.).
Pelagic fish and fishing

The region supports some notable aggregations of prey and apex predators, such as a major lantern fish spawning event in the Queensland Trough, followed synchronously by tunas (McPherson 1991). Black marlin are circum-tropical, but the only known spawning aggregation occurs adjacent to the GBR in the northern half of the Coral Sea (Ueyanagi 1960). Neritic tuna species (e.g. longtail and mackerel tuna) comprise an important component of the Coral Sea pelagic ecosystem. The western fringes of the Coral Sea host one of the few believed spawning locations of the slow-growing longtail tuna (Griffiths et al. 2010). There is a largely unexplored fauna of deepwater (150-500 m) eteline and lutjanid snappers, serranids, carangids, gempylids, bonitos, ariommatids (driftfishes), sharks, and others over the Townsville Trough and the continental slope. These communities, known only from anecdotal evidence, may be similar to ecological communities known to inhabit Indo-Pacific oceanic atoll reefs and seamounts elsewhere. Surprisingly, some of the species identified on Coral Sea fishing vessels are known elsewhere to eat gelatinous plankton, yet they live in depths below the chlorophyll maxima.

There are several fishing sectors within the Coral Sea-commercial, recreational (line and spear) and charter. There are 5 Commonwealth and 15 Queensland fisheries that extend into the Coral Sea territory, although most of the Queensland fisheries' activities do not extend into the territory (Moore et al. 2007). These include hand collectable fisheries, such as aquarium fishes and sea cucumber, demersal fish line and trap, and longline fishing for tropical tuna and billfish. Recreational fishing in the Coral Sea is primarily serviced by the charter boat sector, with long-range vessels that offer spearfishing and gamefishing trips, targeting large pelagic fish (e.g. black marlin and yellowfin tuna) and reef associated sportfish (e.g. giant trevally and dogtooth tuna). Commercial longline fishing is managed within the Eastern Tuna and Billfish Tuna Fishery (Woodhams et al. 2011). Tagging studies of yellowfin tuna in the Coral Sea show a high degree of regional fidelity (Hampton and Gunn 1998), although genetic studies suggest some degree of mixing with neighbouring seas (Grewe and Hampton 2005). Tagging studies of bigeye and longtail tuna also show limited movement between the northwestern 
Coral Sea and neighbouring seas and oceans (Evans et al. 2005, 2008; Griffiths et al. 2011). Whether similar patterns exist for billfish needs further study (Bromhead et al. 2004). Key research questions include the level of connectivity of high level predatory species, particularly tuna and billfish, between the Coral Sea and neighbouring water masses and oceans. Of similar importance is research on predator hot spots in the region and their relationship with seabed topography and indices of oceanic productivity.

\section{Shelf, slope and deep benthic systems}

The Coral Sea's complex geomorphology (Heap and Harris 2008) creates a diverse range of benthic habitats, but the benthic fauna is at an early stage of description. Knowledge of shallow benthic communities is restricted to five reefs and cays (summarised in Ceccarelli 2011). Beyond diving-depths, benthic invertebrates are documented from a shelf-abyssal soft-sediment transect (Alongi 1987, 1992), the Gloria Knolls (Beaman and Webster 2008), and recent ROV studies (Bongaerts et al. 2011). Demersal fishes are known from underwater visual surveys ( $<20 \mathrm{~m}$ depths), baited camera surveys (most recently up to depths of 1,200 m off Osprey Reef), museum collections and demersal surveys. While data for demersal fishes are limited and largely unpublished, they show biogeographic patterns at regional (provincial) and depth zone (bathomic) scales (e.g. Last et al. 2011). Various biogeographically informative groups, such as sharks and rays, differ between the Coral Sea, the GBR and adjacent continental slope and seamounts (Last and White 2011). With the single exception of Alongi and Pichon 1988, there are no studies of benthic ecological processes, or their links to pelagic habitats. Priorities for advancing knowledge of biodiversity and biogeography include developing species-level inventories at reference sites in representative and 'hotspot' habitats, and understanding gene flow, population connectivity and dispersal at intra- and inter-regional scales. This is tractable for well-studied groups, such as ophiuroids, selected crustacea, octocorals and fishes. Effective conservation management requires knowledge of threatened, endangered and exploited species, mechanisms of bentho-pelagic coupling, and the potential role of seamounts and mesophotic communities as climate-change refuges.
Threatened, endangered and protected species

The International Union for the Conservation of Nature (IUCN) lists 341 species of conservation significance in the Coral Sea, including 26 species of cetaceans, 219 species of corals, 21 species of fish, 46 species of sharks and rays, 5 species of marine turtles, and 24 species of birds. Fifty one percent of these species have declining populations. Recently, a number of tuna and billfish species have been added to the IUCN Red List, because of their high exploitation rates and being long-lived and slow-maturing (IUCN 2011). Most of the IUCN-listed species are also listed under the Australian Environment Protection and Biodiversity Conservation (EPBC) Act 1999. The distribution and abundance of most species listed as requiring protection are poorly known in the Coral Sea. Even seabirds and turtles, for which monitoring programs have been carried out in the past, have not been documented beyond a few individual Coral Sea cays. Migration pathways of species that travel through the Coral Sea are also largely unmapped. Current surveys seek to identify the presence of beaked whales, but no other cetacean research is available. The inception or continuation of monitoring programs and associated oceanographic and climate data is crucial, as seabird and turtle monitoring constitutes the only reasonably long-term ecological datasets available for the Coral Sea (e.g. Harvey et al. 2005; Wilcox et al. 2007). Foraging areas for seabirds that nest on Coral Sea cays are unknown and could be resolved through tagging studies and stomach contents analysis. As seabirds and turtles provide a key link between terrestrial and marine communities, field measurements of nutrient fluxes and how they affect soil development and vegetation communities on nutrient-poor islands could be initiated.

\section{Food web studies}

Most primary production in the Coral Sea is from the phytoplankton $<2 \mu \mathrm{m}$ in size, which is primarily grazed by microzooplankton and subsequently lost by respiration in the lower end of the food web. In the epipelagic, mucous net feeders such as pelagic tunicates (mainly larvaceans, salps) and molluscs are able to graze on these cells. Larvaceans are prey items for the larvae of pelagic fishes such as tunas and are important in the foodwebs of oligotrophic oceans. In the 
mesopelagic, there are intriguing indications that other gelatinous zooplankton are key trophic linkages to large deep-water planktivores such as eteline snappers. The interaction of pelagic planktivores, vertically migrating zooplankton and seamounts is also likely to represent an important trophodynamic linkage between the benthos and the pelagic environment.

The trophodynamic linkages in the pelagic realm of the Coral Sea offer exciting opportunities for new research. Understanding the role of mid-trophic species in the food-webs leading to top predators is key to meaningful model development and scenario modelling of impacts of climate change and fishing. Detailed food web descriptions are available for the southern Coral Sea (e.g. Young et al. 2010), but only limited studies exist for the northern Coral Sea. Studies underway are using biochemical techniques to examine trophic dynamics of a range of predators. However, targeted research on the food-webs of major oceanographic features in the remote Coral Sea is lacking.

\section{Ecosystem modelling}

Few ecosystem models currently exist for the region. Griffiths et al. (2010) developed an Ecopath model that predicted climate- and fisheries-related impacts on top fish predators and their prey. This work confirmed that myctophids are a key intermediate trophic level in the Coral Sea. There are two other ecosystem models currently being developed. The first is an end-to-end or 'whole-of-system' model for the Coral Sea using the Atlantis Framework (Fulton et al. 2005). Strategic questions it will address concern protected area management and long-term fishing sustainability. The second ecosystem model being developed is a model of intermediate complexity (Plagany, personal communication). This model will address tactical questions concerning the management and conservation of tuna, billfish and sharks. The utility of ecosystem models in the region could be limited by a lack of information. In particular, critical information is missing on species abundance and distribution of deep water faunal assemblages and benthic endemism on individual seamounts, as well as growth and consumption rates. Key knowledge gaps in our process understanding include predator-prey relationships, bentho-pelagic coupling and nutrientdynamics.

\section{Future priorities and opportunities}

The workshop has helped distil the current scientific knowledge in the Coral Sea, revealing significant gaps in our understanding. We list some of these below.

1. Basic knowledge of biodiversity is lacking The paucity of knowledge of the Coral Sea's benthic fauna constrains understanding and conservation management of proposed Coral Sea Commonwealth Marine Reserve Network ${ }^{1}$ (e.g. Last et al. 2005; Williams et al. 2011). Only 5 of the 18 major emergent reefs and cays have been quantitatively sampled, and even less is known about the plankton and predator communities in the open ocean constituting $99 \%$ of the region, deepsea benthos, demersal fish assemblages in the northern Coral Sea and around many seamounts are particularly data poor. The Coral Sea presents a biogeographic area that is unique to eastern Australia, but its ecology is relatively understudies and frequently highlighted as a knowledge gap (e.g. Last and White 2011).

2. Connectivity between speciose regions The Coral Sea borders the hyper-diverse Great Barrier Reef to the west and the Coral Triangle to the north. Also to the north and east are the developing nations of the western central Pacific with significant tuna and billfish stocks. The connectivity between the Coral Sea and adjacent jurisdictions and water masses has both conservation and sustainability implications and is a significant knowledge gap. Little knowledge exists of finescale physical processes linking habitats of the Coral Sea, or of population connectivity with the GBR or the Coral Triangle, particularly for largescale tuna stocks.

3. Food webs Knowledge is lacking of food-web structure and function associated with ocean currents, the shelf edge, seamounts and islands. Understanding the transfer of energy from lower trophic levels, through mid-trophic species, and to top pelagic predators and to benthic communities is a key uncertainty. This knowledge will be essential for modeling future impacts, particularly fishing and climate change.

\footnotetext{
${ }^{1} \mathrm{http}: / / \mathrm{www} . e n v i r o n m e n t . g o v . a u / c o a s t s / \mathrm{mbp} /$ coralsea/index. html.
} 
4. Ecosystem function There are significant productivity and biodiversity hotspots in the Coral Sea including the black marlin and longtail tuna spawning areas, the tuna feeding aggregations on myctophids off Cairns, and the enhanced productivity associated with the Fraser Island. Physical mechanisms and associated foodwebs that support these hotspots is a ripe area for future research.

5. Unexplored seamounts and plateaux The Coral Sea has a plethora of seamounts and four major plateaux, most of which are unexplored. The Marion and Kenn Plateaux were highlighted as having little information. Understanding the role of seamounts in broader ecosystem function is a priority.

6. Threatened and endangered species The region has important populations of threatened or endangered sea turtles, seabirds and cetaceans. The occurrence and population status of most of these is unknown. There is particularly sparse information on the occurrence of cetaceans such as the beaked whale. Questions remain about whether cetaceans feed in the region.

7. Regional marine planning and protected areas The vast pelagic environment is the last frontier of ocean protection (Game et al. 2009). Working towards a scientific agenda for regional marine planning and protected areas in the Coral Sea, particularly in relation to neighbouring countries.

8. Regional food futures Given the predicted population increases in western Pacific islands and the subsequent demand for protein from the sea, there will be added pressure on fish stocks throughout the region. Ensuring sustainable food futures will be a major international political challenge requiring a sound scientific basis.

9. A real opportunity for international collaboration "The 1982 United Nations Convention of the Law of the Sea (UNCLOS) Part IX places an obligation on countries bordering enclosed seas to cooperate on resource management, the protection of the marine environment and on marine scientific research". Currently there is strong interest from agencies in New Caledonia and New Zealand, particularly for the benthic ecosystem. We have considered here the Australian jurisdiction, but any comprehensive vision for managing the broader Coral Sea must include other bordering nations such as Papua New Guinea, Solomon, New Caledonia (France) and Vanuatu.

Acknowledgments We thank Chris Marshall (DSEWPAC) and Daisy Barham (Protect Our Coral Sea) for their contributions to the workshop. This report benefited from helpful comments by Dr Robert Campbell and Adrian Flynn.

Open Access This article is distributed under the terms of the Creative Commons Attribution Noncommercial License which permits any noncommercial use, distribution, and reproduction in any medium, provided the original author(s) and source are credited.

\section{References}

Alongi DM (1987) The distribution and composition of deep-sea microbenthos in a bathyal region of the western Coral Sea. DeepSea Res I 34:1245-1254

Alongi DM (1992) Bathymetric patterns of deep-sea benthic communities from bathyal to abyssal depths in the western South Pacific (Solomon and Coral Seas). DeepSea Res I 39:549-565

Alongi DM, Pichon M (1988) Bathyal meiobenthos of the western Coral Sea: distribution and abundance in relation to microbial standing stocks and environmental factors. DeepSea Res I 35:491-503

Beaman RJ, Webster JM (2008) Gloria Knolls: a new coldwater coral habitat on the Great Barrier Reef margin. Poster presented at the 2008 Deep-Sea Coral Symposium

Bongaerts P, Kline DI, Hoegh-Guldberg O, Bridge TCL, Muir PR, Wallace CC, Beaman RJ (2011) Mesophotic coral ecosystems on the walls of Coral Sea atolls. Coral Reefs 30:335

Bromhead D, Pepperell J, Wise B, Findlay J (2004) Striped marlin: biology and fisheries. Bureau of Rural Sciences, Canberra

Ceccarelli DM (2011) Australia's Coral Sea: a biophysical profile. Report for the Protect our Coral Sea Coalition, Australia

Cressey D (2011) Australia's marine plans questioned. Nature 480:14-15

Evans K, Clear NP, Patterson T, Gunn JS, Hampton J (2005) Behaviour and habitat preferences of bigeye tuna (Thunnus obesus) tagged in the western Coral Sea. CSIRO, Hobart, and SPC, Noumea, New Caledonia

Evans K, Langley A, Clear NP, Williams P, Patterson T, Sibert J, Hampton J, Gunn JS (2008) Behaviour and habitat preferences of bigeye tuna (Thunnus obesus) and their influence on longline fishery catches in the western Coral Sea. Can J Fish Aquat Sci 65:2427-2443

Fulton EA, Smith ADM, Punt AE (2005) Which ecological indicators can robustly detect effects of fishing? ICES J Mar Sci 62:540-551

Game ET, Grantham HS, Hobday AJ, Pressey RL, Lombard AT, Beckley LE, Gjerde K, Bustamante R, Possingham HP, Richardson AJ (2009) Pelagic protected areas: the missing dimension in ocean conservation. Trends Ecol Evol 24:360-369

Grewe PM, Hampton J (2005) An assessment of bigeye (Thunnus obesus) population structure in the Pacific Ocean, based on 
mitochondrial DNA and DNA microsatellite analysis. CSIRO, Hobart, and SPC, Noumea, New Caledonia

Griffiths FB, Wadley VA (1986) A synoptic comparison of fishes and crustaceans from a warm-core eddy, the East Australian Current, the Coral Sea and the Tasman Sea. DeepSea Res I 33:1907-1922

Griffiths SP, Young JW, Lansdell MJ, Campbell RA, Hampton J, Hoyle SD, Langley A, Bromhead D, Hinton MG (2010) Ecological effects of longline fishing and climate change on the pelagic ecosystem off eastern Australia. Rev Fish Biol Fish 20:239-272

Griffiths SP, Lam CH, Zischke M (2011) Restricted vertical and cross-shelf movements of longtail tuna (Thunnus tonggol) in Australian waters as determined by pop-up archival tags. Report to the IOTC Working Party on Neritic Tunas, Chennai, India, 14-16 November, 2011

Halpern BS, Walbridge S, Selkoe KA, Kappel CV, Micheli F, D'Agrosa C, Bruno JF, Casey KS, Ebert C, Fox HE, Fujita R, Heinemann D, Lenihan HS, Madin EMP, Perry MT, Selig ER, Spalding M, Steneck R, Watson R (2008) A global map of human impact on marine ecosystems. Science 319:948-952

Hampton J, Gunn J (1998) Exploitation and movements of yellowfin tuna (Thunnus albacares) and bigeye tuna ( $T$. obesus) tagged in the north-western Coral Sea. Mar Freshw Res 49:475-489

Harvey T, Townsend S, Kenyon N, Redfern G (2005) Monitoring of nesting sea turtles in the Coringa-Herald National Nature Reserve (1991/92-2003/04 nesting seasons). IndoPacific Sea Turtle Conservation Group, Inc., Townsville

Heap AD, Harris PT (2008) Geomorphology of the Australian margin and adjacent seafloor. Aus J Earth Sci 55:555-585

Hobday AJ (2010) Ensemble analysis of the future distribution of large pelagic fishes off Australia. Prog Oceanogr 86:291-301

Kloser RJ, Ryan TE, Young JW, Lewis ME (2009) Ocean basin scale acoustic observations of mid-trophic fishes, potential and challenges. ICES J Mar Sci 66:998-1006

Lansdell M, Young J (2007) Pelagic cephalopods from eastern Australia: species composition, horizontal and vertical distribution determined from the diets of pelagic fishes. Rev Fish Biol Fish 17:125-138

Last PR, White WT (2011) Biogeographic patterns in the Australian chondrichthyan fauna. J Fish Biol 79:1193-1213

Last P, Lyne V, Yearsley G, Gledhill D, Gomon M, Rees T, White W (2005) Validation of the national demersal fish datasets for the regionalisation of the Australian continental slope and outer shelf ( $>40 \mathrm{~m}$ depth). Department of Environment and Heritage and CSIRO Marine Research, Australia
Last PR, White WT, Gledhill DC, Pogonoski JJ, Lyne V, Bax NJ (2011) Biogeographical structure and affinities of the marine demersal ichthyofauna of Australia. J Biogeography 38:1484-1496

McPherson GR (1991) Reproductive biology of yellowfin tuna in the eastern Australian Fishing Zone, with special reference to the north-western Coral Sea. Aus J Mar Freshwater Res 42:465-477

Moore A, Summerson R, Sahlqvist P, Kellett S, McNee A, Maller C, Vieira S, Stakelum P, Larcombe J, Woodhams J, Pickworth J (2007) Description of commercial, recreational and charter fishing activities. Bureau of Rural Sciences, Canberra

Mora C, Myers RA, Coll M, Libralato S, Pitcher TJ, Sumalia RU, Zeller D, Watson R, Gaston KJ, Worm B (2009) Management effectiveness of the world's marine fisheries. PLoS Biol 7:e1000131. doi:10.1371/journal.pbio.1000131

Suthers IM, Taggart CT, Kelley D, Rissik D, Middleton JH (2004) Entrainment and advection in an island's tidal wake, as revealed by light attenuance, zooplankton and ichthyoplankton. Limnol Oceanogr 49:283-296

Suthers IM, Taggart CT, Rissik D, Baird ME (2006) Day and night ichthyoplankton assemblages and zooplankton biomass size spectrum in a deep ocean island wake. Mar Ecol Prog Ser 322:225-238

Ueyanagi S (1960) On the larvae and the spawning area of the shirokajiki, Marlina marlina (Jordan and Hill). Rep Nankai Reg Fish Lab 12:85-96

Wilcox C, Dell J, Baker B (2007) A preliminary investigation on the relationship between variation in oceanography and seabird abundance in Coringa Herald National Nature Reserve. Report for the Department of the Environment and Water Resources by Latitude 42 Environmental Consultants Pty Ltd, Hobart

Williams A, Althaus F, Clark MR, Gowlett-Holmes KG (2011) Composition and distribution of deepsea benthic invertebrate megafauna on the Lord Howe Rise and Norfolk Ridge, southwest Pacific Ocean. DeepSea Res II 58:948-958

Woodhams J, Stobutzki I, Vieira S, Curtotti R, Begg GA (eds) (2011) Fishery status reports 2010: status of fish stocks and fisheries managed by the Australian Government. Australian Bureau of Agricultural and Resource Economics and Sciences, Canberra

Young JW, Lansdell MJ, Cooper SP, Campbell RA, Juanes F, Guest MA (2010) Feeding ecology and niche segregation in oceanic top predators off eastern Australia. Mar Biol 15:2347-2368 